\title{
Geochemistry of Sphalerite from the Permian Volcanic-Hosted Massive Sulphide (VHMS) Deposits in the Tasik Chini Area, Peninsular Malaysia: Constraints for Ore Genesis
}

\author{
Mohd Basril Iswadi Basori ${ }^{1, *} \mathbb{( D}$, Sarah E. Gilbert ${ }^{2} \mathbb{D}$, Khin Zaw ${ }^{3} \mathbb{D}$ and Ross R. Large ${ }^{3}$ \\ 1 Department of Earth Sciences and Environment, Faculty of Science and Technology, \\ The National University of Malaysia (UKM), Selangor 43600, Malaysia \\ 2 Adelaide Microscopy, The University of Adelaide, Frome Road, Adelaide, SA 5005, Australia; \\ sarah.gilbert@adelaide.edu.au \\ 3 Centre for Ore Deposits and Earth Sciences, University of Tasmania, Hobart, TAS 7001, Australia; \\ Khin.Zaw@utas.edu.au (K.Z.); Ross.Large@utas.edu.au (R.R.L.) \\ * Correspondence: basril@ukm.edu.my; Tel.: +603-8921-5572; Fax: +603-8921-5490
}

Citation: Basori, M.B.I.; Gilbert, S.E.; Zaw, K.; Large, R.R. Geochemistry of Sphalerite from the Permian Volcanic-Hosted Massive Sulphide (VHMS) Deposits in the Tasik Chini Area, Peninsular Malaysia: Constraints for Ore Genesis. Minerals 2021, 11, 728. https://doi.org/ $10.3390 / \min 11070728$

Academic Editors: Emilio Pascual, Teodosio Donaire and Manuel Toscano

Received: 7 April 2021

Accepted: 2 July 2021

Published: 5 July 2021

Publisher's Note: MDPI stays neutral with regard to jurisdictional claims in published maps and institutional affiliations.

Copyright: (c) 2021 by the authors. Licensee MDPI, Basel, Switzerland. This article is an open access article distributed under the terms and conditions of the Creative Commons Attribution (CC BY) license (https:// creativecommons.org/licenses/by/ $4.0 /)$.

\begin{abstract}
The Bukit Botol and Bukit Ketaya deposits are two examples of volcanic-hosted massive sulphide (VHMS) deposits that occur in the Tasik Chini area, Central Belt of Peninsular Malaysia. The mineralisation is divided into subzones distinguished by spatial, mineralogical, and textural characteristics. The primary sulphide minerals include pyrite, chalcopyrite, sphalerite, and galena, with lesser amounts of Sn- and Ag-bearing minerals, with Au. However, pyrrhotite is absent from both deposits. This study presents the results of sphalerite chemistry analysed by using an electron microprobe. Two types of sphalerite are recognised: sphalerite from the Bukit Botol deposit reveals a range of $<$ DL to 24.0 mole $\% \mathrm{FeS}$, whereas sphalerite from the Bukit Ketaya deposit shows a range of $<$ DL to 3 mole\% FeS. Significant variations are shown in $\mathrm{Zn}, \mathrm{Cu}, \mathrm{Cd}$, and Ag levels. Although the sphalerite has a wide variation in composition, a discernible decreasing Fe trend is exhibited from the stringer zone towards massive sulphide. This compositional variation in sphalerites may in part reflect variable temperature and activity of sulphur in the hydrothermal fluids during ore formation. Alternatively, the bimodal composition variations suggest that mineral chemistry relates to contrasting depositional processes. The $\mathrm{Zn} / \mathrm{Cd}$ ratios for sphalerite from both these deposits are similar to those exhibited by volcano-sedimentary deposits with a volcanic origin. Therefore, the consistently low $\mathrm{Cd}$ concentrations and moderate to high $\mathrm{Zn} / \mathrm{Cd}$ ratios suggest mixing of seawater and minor magmatic fluids controlling the chemistry of sphalerite at both deposits during their formation.
\end{abstract}

Keywords: sphalerite; mineral chemistry; fluid; VHMS; Tasik Chini; Peninsular Malaysia

\section{Introduction}

The concentrations of $\mathrm{Fe}, \mathrm{Mn}$, and $\mathrm{Cd}$ in sphalerite can be related to compositional variations in ore-forming fluids for many ore deposits of different genesis (e.g., [1,2]), and provide important information on the changes in temperature and chemistry of mineralising fluids (e.g., [3]). Sphalerite can be enriched in a wide variety of elements, such as Fe, $\mathrm{Mn}, \mathrm{Cd}, \mathrm{Cu}, \mathrm{Sn}, \mathrm{Ag}, \mathrm{Ga}$, and In [4], potentially influencing the economic value of a zinc sulphide deposit [5]. For example, sphalerite is the most important source of In in many $\mathrm{Sn}$ polymetallic deposits [6].

The potential application of the FeS contents as an indicator for fluid origin and its temperature of deposition was first recognised by [7]. The Fe composition of sphalerite in assemblages with pyrite and pyrrhotite is widely known as a sphalerite geobarometer [8]. Therefore, the Fe content in sphalerite has been applied to measure the pressure and depth of many metamorphosed massive sulphide deposits with variable success (e.g., [9-13]), although there is some controversy over the application of this method [14]. 
Sphalerite with low FeS contents (pale coloured sphalerite) forms at a relatively lower temperature from oxidising solutions [15-17]. The author of [13] noted that the sphalerite from the ancient Rosebery volcanic-hosted massive sulphide (VHMS) deposit has variable $\mathrm{FeS}$ content $(0-20 \mathrm{~mole} \%)$ due to changes in the sulphur activity $\left(f \mathrm{~S}_{2}\right)$ and related metamorphism. In other cases, [18] also interpreted the uniformly high FeS contents of sphalerite at Thalanga (8 to $12 \mathrm{~mole} \% \mathrm{FeS}$ ), as relating to sphalerite-pyrite recrystallisation and re-equilibration during peak metamorphism. The author of [19] used the FeS content of sphalerite to differentiate between high temperature $\mathrm{Zn}-\mathrm{Cu}$-rich (high $\mathrm{FeS}$ ) and low temperature $\mathrm{Zn}$-rich (low FeS) sulphide mineralisation in some Archean Canadian VHMS deposits. In actively forming seafloor hydrothermal deposits, the FeS contents of sphalerite show a wide variation from as low as 0 to $20 \mathrm{~mole} \% \mathrm{FeS}$, ranging up to $44 \mathrm{~mole} \% \mathrm{FeS}$ [20-22] that has been attributed to periodic changes in sulphur fugacity $\left(f \mathrm{~S}_{2}\right)$ or $\mathrm{H}_{2} \mathrm{~S}$ during sphalerite and wurtzite deposition [23,24].

This paper presents an interpretation of the chemical compositions of sphalerite from the Permian VHMS deposits in the Tasik Chini area, Peninsular Malaysia. The primary objectives of this study are to evaluate: variations in trace element compositions of these minerals within the mineralised system, variations in trace element contents among different textural varieties and paragenetic stages of the system, and geochemistry constraints on the ore genetic type.

\section{General Setting and Deposit Geology}

The Central Belt of Peninsular Malaysia occurs in the East Malaya Terrane ([25]; Figure 1). It comprises Permo-Triassic deep to shallow marine clastic sediments and limestones with abundant felsic volcanic and volcaniclastic rocks of a palaeo-arc setting [26,27], and is unconformably overlain by the Jurassic-Cretaceous flysch sequences [28]. All these rocks were regionally deformed and metamorphosed to very low-grade greenschist facies as a result of regional structural deformation $[27,28]$. The belt is also well known for its widespread association with extrusive and intrusive rocks $[29,30]$. The magmatism is characterized by I and S-types, calc-alkaline to alkaline granitoids that were generated by subduction-related processes [31].

The Tasik Chini area is situated in the southern part of Pahang, Peninsular Malaysia. Regional geological study of the district has been described by [32] and recently by [33,34]. In general, the area is composed mainly of Permo-Triassic sedimentary and volcanic rocks that are overlain by Jurassic to Cretaceous continental, predominantly red bed units. Quaternary sediments are dominant towards the eastern edge of the continental sequence. The Bukit Botol and Bukit Ketaya deposits are the two most extensively explored mineralisations in the Tasik Chini area (e.g., [35-37]; Figure 1). The mineralisations are hosted within the Permo-Triassic sedimentary and volcanic host rocks succession. The ore mineralisations are of hydrothermal origin, and were classified as an example of Permian VHMS deposit type [33,34]. 


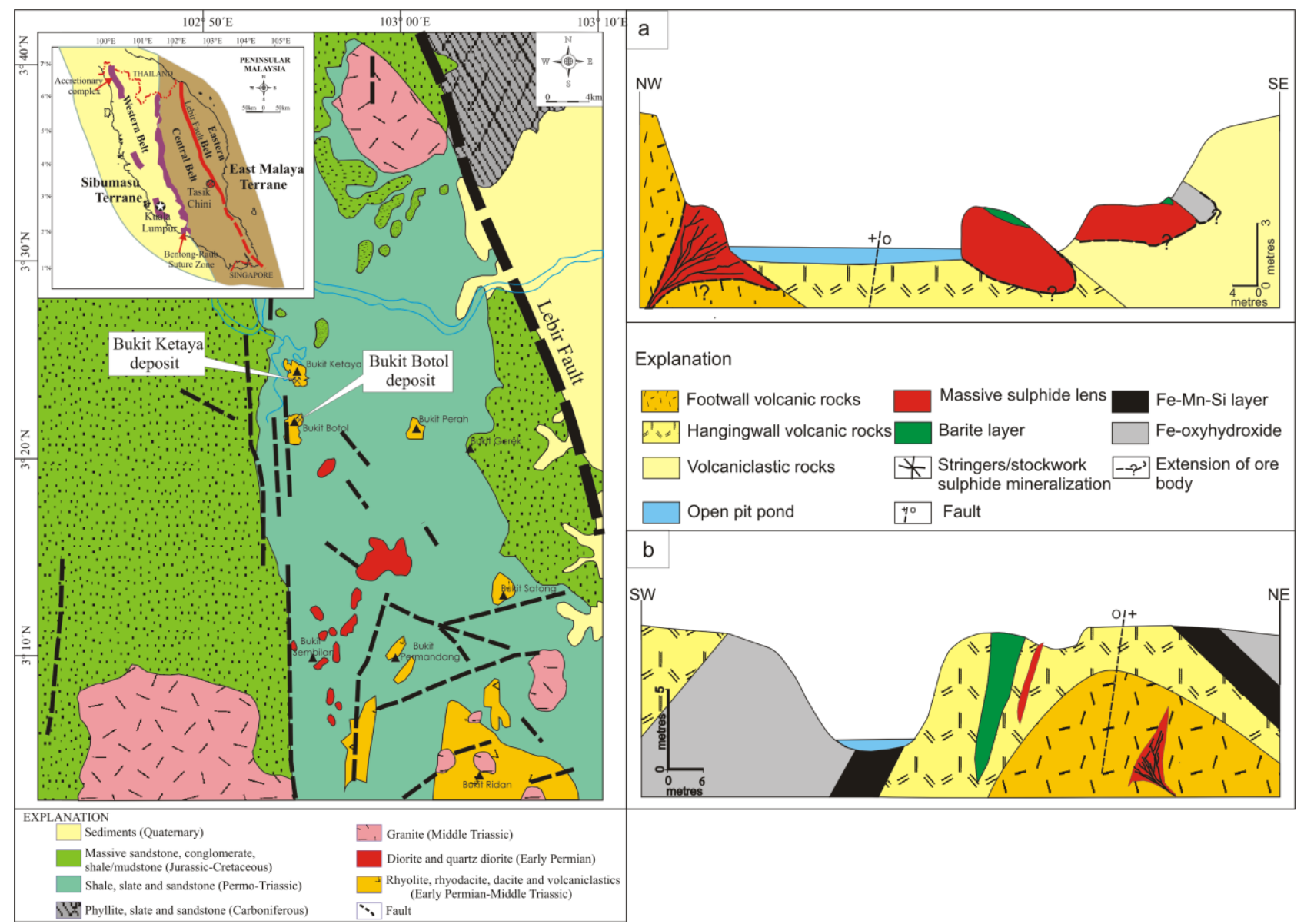

Figure 1. Map showing the location of Tasik Chini VHMS deposit on the East Malaya Terrane, and the location of Bukit Botol and Bukit Ketaya deposits in the regional geology the Tasik Chini area, Peninsular Malaysia (modified after [33]); (a) Representative cross-section through the Bukit Ketaya deposit showing the stratigraphic sequence and mineralisation styles (modified from [33]); (b) Cross-section of the Bukit Botol deposit showing the stratigraphic sequence and mineralisation styles (modified from [33]).

The Bukit Botol deposit shows four types of classic VHMS mineralisations, which are vertically zoned from the bottom to the top, including (1) sulphide-rich stockwork veins with disseminated sulphides, (2) massive sulphide lenses, (3) a thin barite layer, and (4) a Fe-Mn \pm Si layer (Figure 1a). The massive sulphide zones are present as several small lenses, and are separated and offset by faulting. However, there is no significant effect at either the mineralisation and host rocks of the Bukit Botol deposit [34]. A well-mineralised zone of the sulphide stringer veins is commonly surrounded by silicification to chloritisation. A Fe-Mn \pm Si layer is well developed at the top of the massive sulphides [33,34]. Similarly, mineralisation at the Bukit Ketaya deposit is dominated by barite and Fe-Mn \pm Si layers of orebodies with minor/small stockwork-like zones and thin layers of massive sulphide mineralisation. Both the mineralisation and host rocks are offset and occupy the axial plane of a faulted and folded, south-east trending syncline [34].

In general, the Fe-Mn \pm Si layer extends along strike and downdip, closely associated with the barite lens, and caps the zone of thin sheets and stringers of massive sulphides (Figure 1b). The petrographic characteristics and geochemistry data from the Bukit Botol and Bukit Ketaya Fe-Mn \pm Si layers indicate that these layers are products of exhalative processes associated with hydrothermal activity [38].

The main sulphide mineral assemblages of both Bukit Botol and Bukit Ketaya are largely pyrite as the major mineral, with subordinate chalcopyrite, sphalerite, and rare galena. Additionally, traces of Sn- and Ag-bearing minerals, with Au, are also present in 
the massive sulphide and barite layers. Chalcopyrite, Ag-bearing minerals, and Au are locally abundant at the Bukit Botol deposit compared to the Bukit Ketaya deposit [33,34].

The most widely accepted model for this belt suggests that the Central Belt of Peninsular Malaysia has experienced a complex tectonic evolution that involves Paleozoic-Early Mesozoic subduction-collision, and Late-Mesozoic post-collision tectonics of the Tethys Ocean [25]. Current data suggest that the Central Belt formed as an island-arc-back-arc environment related to the subduction process (e.g., [34,39]). The Central Belt of Peninsular Malaysia represents the Permian volcanic arc that formed along the margin of the East Malaya Terrane [25,39,40]. The Lebir Fault Zone is a suture zone marking the closed back-arc basin developed on the margin of the Permian East Malaya volcanic arc between the Central and Eastern Belts [33,41]. Based on geochemical, geochronological, Pb, and $S$ isotopic characteristics and fluid inclusions data of the Permian VHMS deposits in the Tasik Chini area, the formation could have accompanied this back-arc basin evolution (e.g., $[33,38,42-45])$.

\section{Analytical Methods}

The composition of sphalerite from the Bukit Botol and Bukit Ketaya deposits was obtained in different mineralisation styles from the massive sulphide lenses and stockwork zones. The analysed samples are from the same polished thin sections and mounted epoxy blocks used for reflected microscopic observation. Detailed petrographic analysis was also performed to avoid the texture of "chalcopyrite disease" and micro-inclusions in the sphalerite using back-scattered electron (BSE) images. A total of 271 spot analyses were carried out on sphalerite: 78 from the the Bukit Botol deposit (54 of massive sulphide lens, 24 of stringer zone) and 93 from the Bukit Ketaya deposit (45 of massive sulphide lens, 48 of stringer zone) from 31 samples.

Chemical analyses were made at the Central Science Laboratory (CSL), University of Tasmania, using a Cameca SX50 electron microprobe (EPMA) with the following analytical conditions: acceleration voltage, $20 \mathrm{kV}$, beam current at $20 \mathrm{nA}$ and $5-10 \mu \mathrm{m}$ probe diameter. Raw count data were corrected using a ZAF correction program. Concentrations of $\mathrm{S}, \mathrm{Pb}$, $\mathrm{Ag}, \mathrm{Cu}, \mathrm{Zn}, \mathrm{Sn}, \mathrm{Sb}, \mathrm{As}, \mathrm{Mn}, \mathrm{Fe}$, and $\mathrm{Cd}$ were measured at each point. However, compositions of $\mathrm{Pb}, \mathrm{Sn}, \mathrm{Sb}$, As and $\mathrm{Mn}$ were very low or below detection limits. The standards for correction were natural sphalerite $(\mathrm{ZnS})$ for $\mathrm{Zn}$ and $\mathrm{S}$, galena for $\mathrm{Pb}$, marcasite for $\mathrm{Fe}$, cassiterite for $\mathrm{Sn}$, stibnite for $\mathrm{Sb}$, cuprite for $\mathrm{Cu}$, synthetic gallium-arsenide for As and synthetic pure metals $\mathrm{Au}, \mathrm{Ag}$ and $\mathrm{Cd}$. Detection limits of the microprobe analyses were as follows: $\mathrm{S}$ $(0.14 \mathrm{wt} \%), \mathrm{Pb}(0.10 \mathrm{wt} \%), \mathrm{Ag}(0.06 \mathrm{wt} \%), \mathrm{Cu}(0.02 \mathrm{wt} \%), \mathrm{Zn}(0.08 \mathrm{wt} \%), \mathrm{Sn}(0.02 \mathrm{wt} \%), \mathrm{Sb}$ $(0.02 w t \%)$, As $(0.02 w t \%), \operatorname{Mn}(0.01 w t \%)$, Fe (-0.01 wt \%), and Cd $(0.02 w t \%)$.

Several methods have been proposed for treating below-detection limit $(<\mathrm{BL})$ datasets, and each of these methodologies has strengths and limitations. Thus, in this paper, a method commonly used by replacing all readings below the detection limit with a zero (0) as suggested by [46], is used for the treatment of measurements below the detection limit data.

\section{Results}

\subsection{Sphalerite Types and Textures}

Sphalerite types and textural variations from the Bukit Botol and Bukit Ketaya deposits are shown in Figure 2. At the Bukit Botol deposit, sphalerite forms as a fine-grained to irregular grain type and occurs in all mineralisation styles. The fine-grained sphalerite intergrown with galena are associated with overgrowths on pyrite and are most commonly abundant in the stringer zones (Figure 2a). Meanwhile, the irregular-shaped sphalerite is up to $500 \mu \mathrm{m}$ in size, intergrown with galena, pyrite, and chalcopyrite (Figure 2b). Several inclusions of fine-grained, subhedral to rounded Sn-bearing minerals, namely cassiterite and stannite or mohite, occur within this sphalerite, and are present in both massive and stringer mineralisation (Figure 2c). 


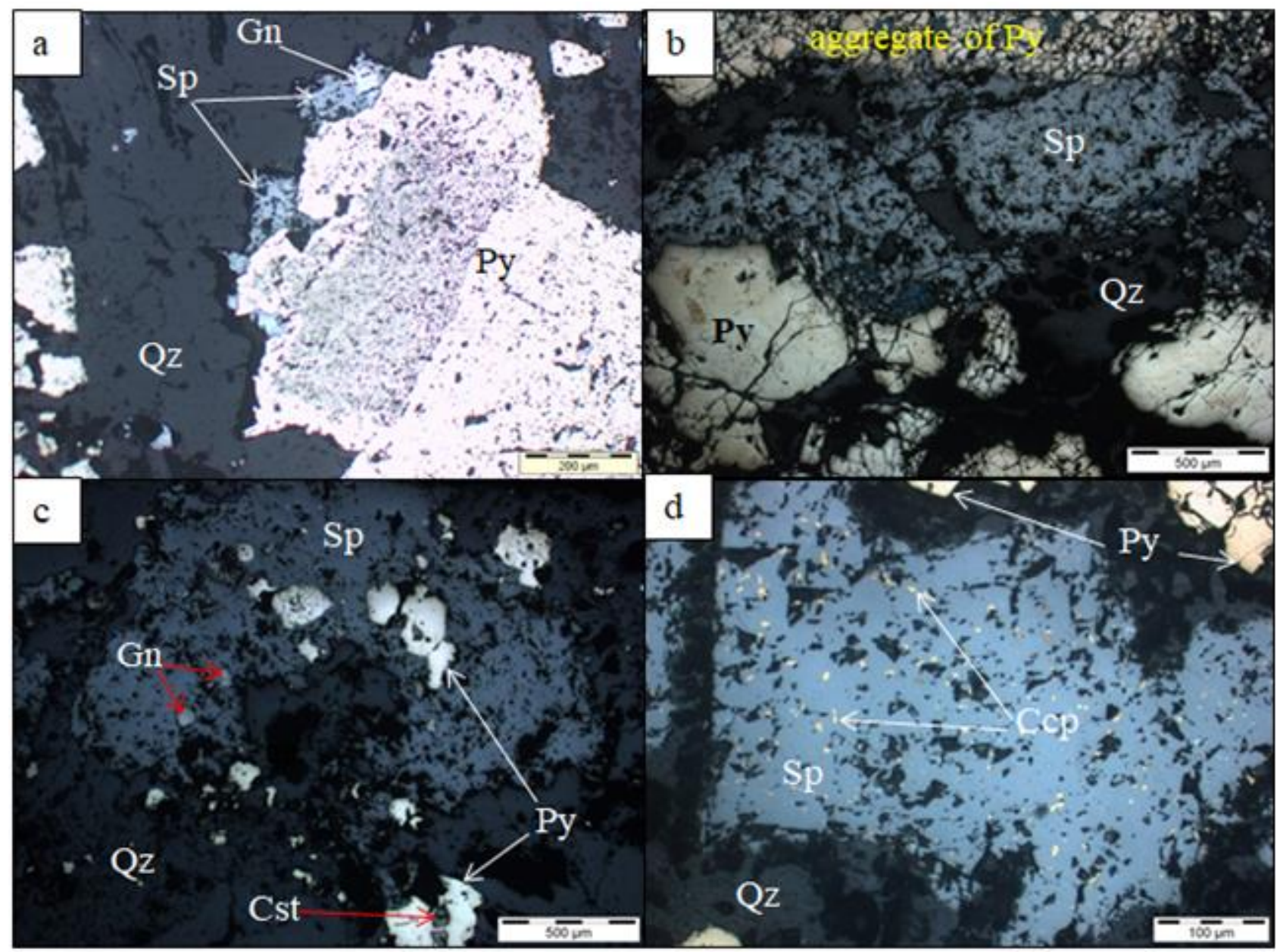

Figure 2. Reflected light photomicrographs showing petrographic aspects of sphalerite samples from Bukit Botol (a-c) and Bukit Ketaya (d). (a) The fine-grained sphalerite intergrown with galena are associated with overgrowths on pyrite and are most commonly abundant in the stringer zones; (b) The irregular-shaped sphalerite is up to $500 \mu \mathrm{m}$ in size, intergrown with galena, pyrite and chalcopyrite; (c) Several inclusions of fine-grained, subhedral to rounded Sn-bearing minerals occur in this sphalerite, and are present in both massive and stringer mineralization; (d) Sphalerite exhibiting chalcopyrite disease showing irregular inclusions of chalcopyrite within sphalerite. Annotation: $\mathrm{Ccp}=$ chalcopyrite, $\mathrm{Gn}=$ galena, $\mathrm{Sp}=\mathrm{sphalerite}$, Cst $=$ Sn mineral, $\mathrm{Py}=$ pyrite and $\mathrm{Qz}=$ quartz (according to [47]).

Similarly, sphalerite is found as isolated crystals together with other sulphides at the Bukit Ketaya deposit. Some crystals display evidence of having filled micro-cavities or micro-fissures. The isolated sphalerite crystals accompanied by pyrite and galena normally contain chalcopyrite inclusions, examples of chalcopyrite "disease" texture that is commonly observed in metamorphosed massive sulphide deposits ([3]). These inclusions are irregularly distributed (Figure 2d), or commonly arranged, in a wavy pattern roughly parallel to the crystallographic planes. The disease texture is weakly developed both in the thin massive sulphide lens and in stockwork zones. Considering the complex paragenetic relationships between the major sulphide minerals, textural variants, and the unaffected chalcopyrite disease texture (although it has been subjected to very low-grade greenschist facies metamorphism) of the same phase, it is inferred that the dominant minerals, such as pyrite, galena and sphalerite are primary, since they occur either as co-crystallised with mutual boundary relations or occur as host minerals in which secondary minerals are housed and intergrown. The variability of mineral textures in sphalerites from both the deposits could possibly suggest variable fluid conditions during sphalerite growth due to physico-chemical changes in the parental fluids, with minor local structural deformation and remobilization. 


\subsection{Chemical Compositions of Sphalerite}

\subsubsection{Fe Content}

Overall, the samples show variation in Fe content. The FeS composition of sphalerite for the Bukit Botol deposit exhibits a consistent value from $<\mathrm{DL}$ to $24.0 \mathrm{~mole} \% \mathrm{FeS}$. The consistency low level of $\mathrm{FeS}$ in massive sulphide, ranging from 0.3 to $1.8 \mathrm{~mole} \% \mathrm{FeS}(n=54)$, is distinguished from the higher and more variable range of FeS content from 4.5 to 23.5 mole $\% \mathrm{FeS}(n=24)$ in the stringer zones (Figure 3), and falls in low Fe-sphalerite and higher-intermediate Fe-sphalerite in Zn vs. Fe binary diagram, respectively (Figure 4).

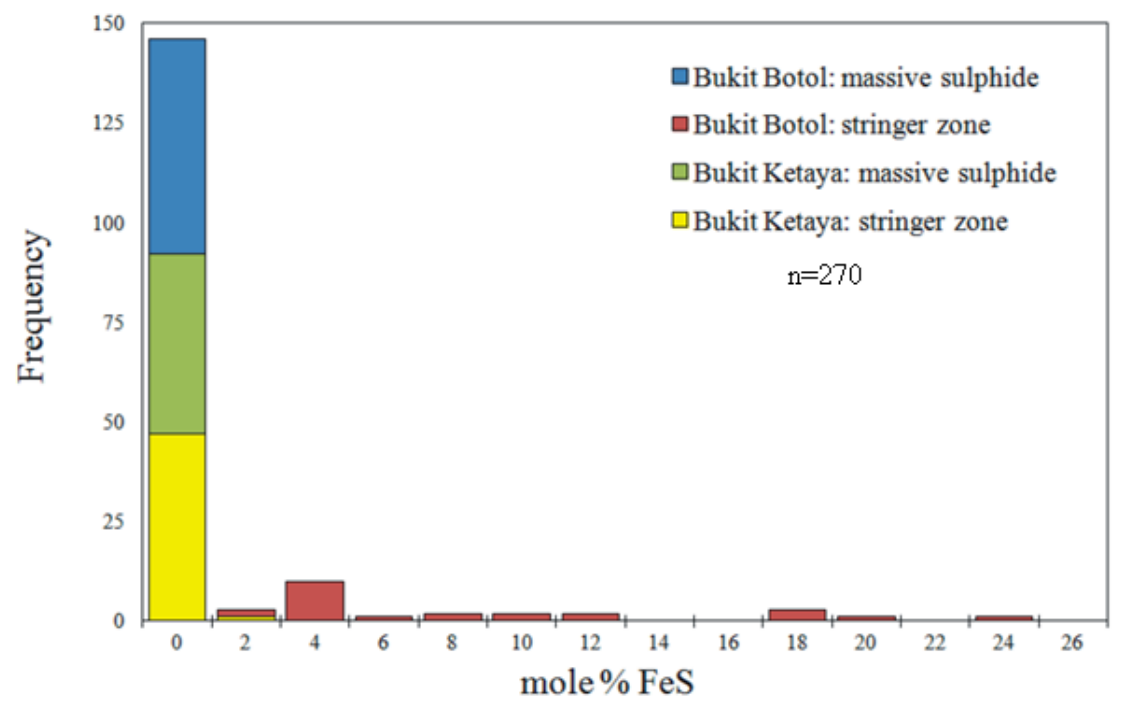

Figure 3. Frequency distribution diagram for the mole\% FeS in sphalerite from the Bukit Botol and Bukit Ketaya deposits, Central Peninsular Malaysia.

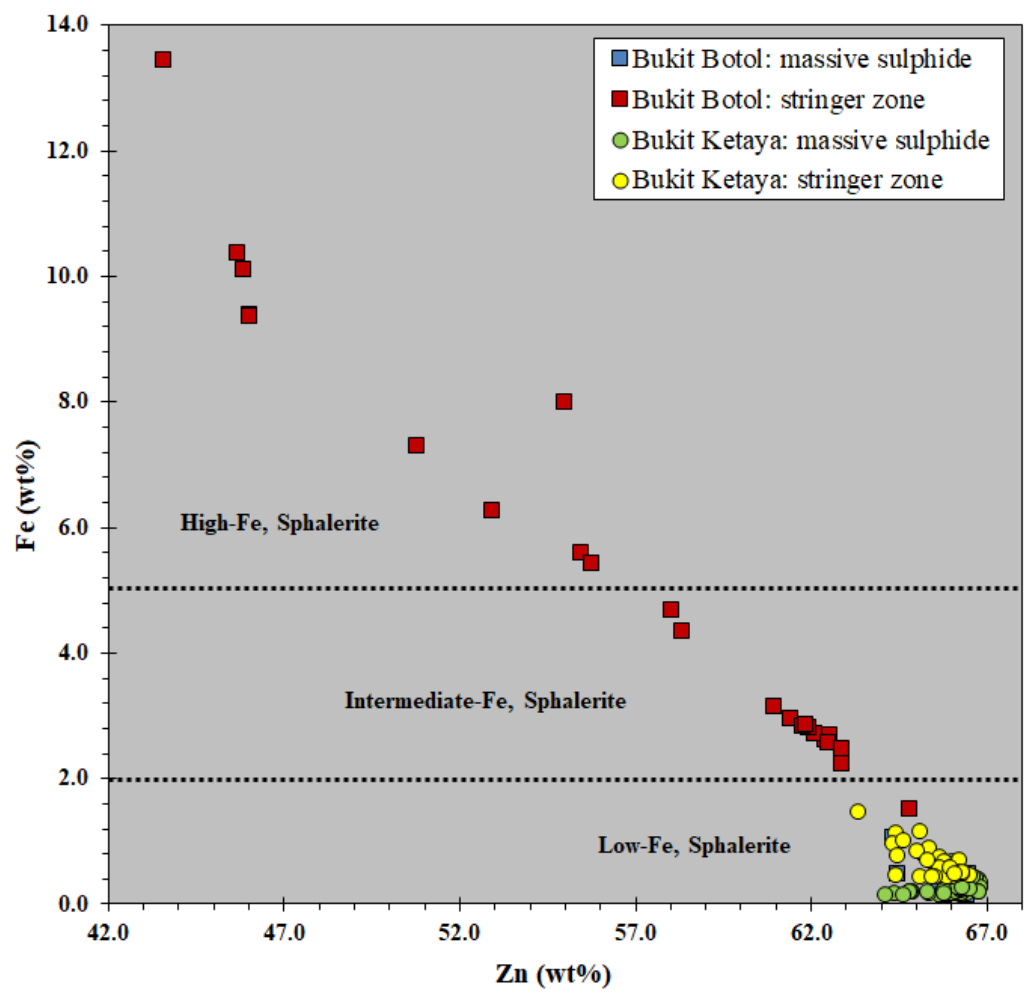

Figure 4. Binary plot of varying Fe and Zn compositions in sphalerite from the Bukit Botol and Bukit Ketaya deposits, Central Peninsular Malaysia. 
In comparison, there are no significant variations in FeS content among the sphalerites of different types of mineralisation from the Bukit Ketaya deposit. The FeS content in sphalerite is lower and more homogeneous, with a narrow compositional range of $0.3-1.2$ mole $\% \mathrm{FeS}(n=45)$ from the massive sulphide compared to slightly higher in the stringer zones at a range of $0.7-2.5 \mathrm{~mole} \% \mathrm{FeS}(n=48)$ (Figure 2). The variation in Fe content between the massive sulphide and stringer zones is mostly plotted in a low Fe-sphalerite in the $\mathrm{Zn}$ vs. Fe binary diagram (Figure 4).

\subsubsection{Minor Element Contents}

The average chemical composition of representative sphalerite from different types of mineralisations at the Bukit Botol and Bukit Ketaya deposits is summarised in Tables 1-4. A large variation in minor elements of sphalerite from the Bukit Botol and Bukit Ketaya deposits is measured by EPMA. The $\mathrm{Cu}, \mathrm{Cd}$, and $\mathrm{Ag}$ are relatively enriched, from 100 to 64,000 ppm, 1800 to $5700 \mathrm{ppm}$, and 100 to $1000 \mathrm{ppm}$. The $\mathrm{Cd}$ range content of sphalerite is similar in both deposits, and roughly correlates with Fe content. For $\mathrm{Ag}$, the concentration in the samples from Bukit Botol exhibit a significant variation, from $100 \mathrm{ppm}$ in the massive sulphide sample to more than $600 \mathrm{ppm}$ in stringer zones, whereas the majority of the samples from Bukit Ketaya contain amounts of Ag in the 100-600 ppm (10 out of 17 samples). Occasionally, excluding the $\mathrm{Cd}$ and $\mathrm{Ag}$ contents, the composition of $\mathrm{Cu}$ shows a more uniform enrichment in the stringer zones than those in the massive sulphide lenses at both the deposits. The $\mathrm{Pb}, \mathrm{Sn}, \mathrm{Sb}, \mathrm{As}$, and $\mathrm{Mn}$ contents are consistently below detection limit of the instrument, but were also detected in a few samples.

Table 1. Average chemical compositions of the representative sphalerite in a massive sulphide lens from the Bukit Botol deposit, Central Peninsular Malaysia.

\begin{tabular}{|c|c|c|c|c|c|c|c|}
\hline \multirow{2}{*}{$\begin{array}{c}\text { Deposit } \\
\text { Ore } \\
\text { Type/Sample }\end{array}$} & \multicolumn{7}{|c|}{ Bukit Botol } \\
\hline & MS: BB1d & MS: BB1d-A & MS: BB1d-B & MS: BB1d-C & MS: BB1d-D & MS: BB1d-E & MS: BB1d-F \\
\hline $\begin{array}{c}\text { No. spot } \\
\text { (Average wt } \% \text { ) }\end{array}$ & 10 & 6 & 10 & 5 & 8 & 5 & 10 \\
\hline S & 32.98 & 33.08 & 33.14 & 33.23 & 33.08 & 32.91 & 32.90 \\
\hline $\mathrm{Pb}$ & $<\mathrm{DL}$ & $<\mathrm{DL}$ & $<\mathrm{DL}$ & 0.02 & $<\mathrm{DL}$ & $<\mathrm{DL}$ & 0.01 \\
\hline $\mathrm{Ag}$ & 0.01 & 0.03 & 0.01 & $<\mathrm{DL}$ & $<\mathrm{DL}$ & 0.04 & 0.02 \\
\hline $\mathrm{Cu}$ & 0.21 & 0.34 & 0.13 & 0.26 & 0.17 & 0.11 & 0.11 \\
\hline $\mathrm{Zn}$ & 66.01 & 65.72 & 66.11 & 65.91 & 65.81 & 66.13 & 66.09 \\
\hline $\mathrm{Sn}$ & $<$ DL & $<\mathrm{DL}$ & $<\mathrm{DL}$ & $<$ DL & $<\mathrm{DL}$ & $<$ DL & $<\mathrm{DL}$ \\
\hline $\mathrm{Sb}$ & $<\mathrm{DL}$ & $<\mathrm{DL}$ & 0.00 & $<\mathrm{DL}$ & 0.01 & $<\mathrm{DL}$ & 0.00 \\
\hline As & 0.00 & $<\mathrm{DL}$ & $<\mathrm{DL}$ & $<\mathrm{DL}$ & $<\mathrm{DL}$ & $<\mathrm{DL}$ & $<\mathrm{DL}$ \\
\hline $\mathrm{Mn}$ & 0.00 & $<\mathrm{DL}$ & 0.09 & 0.01 & $<\mathrm{DL}$ & $<\mathrm{DL}$ & 0.01 \\
\hline $\mathrm{Fe}$ & 0.38 & 0.51 & 0.43 & 0.50 & 0.40 & 0.23 & 0.22 \\
\hline $\mathrm{Cd}$ & 0.53 & 0.53 & 0.53 & 0.56 & 0.57 & 0.54 & 0.51 \\
\hline \multicolumn{8}{|l|}{ Average } \\
\hline $\mathrm{Zn} / \mathrm{Mn}$ & 1093 & 0 & 948 & 3395 & 0 & 0 & 2608 \\
\hline $\mathrm{Zn} / \mathrm{Cd}$ & 124 & 124 & 126 & 117 & 115 & 122 & 130 \\
\hline $\mathrm{Zn} / \mathrm{Fe}$ & 176 & 151 & 158 & 147 & 168 & 288 & 310 \\
\hline \multicolumn{8}{|l|}{ Mole \% } \\
\hline FeS & 0.64 & 0.85 & 0.72 & 0.83 & 0.67 & 0.39 & 0.37 \\
\hline $\mathrm{CdS}$ & 0.54 & 0.54 & 0.54 & 0.57 & 0.58 & 0.55 & 0.52 \\
\hline $\mathrm{CuS}$ & 0.32 & 0.52 & 0 & 0.40 & 0.26 & 0 & 0 \\
\hline $\mathrm{ZnS}$ & 98.50 & 98.09 & 98.74 & 98.20 & 98.49 & 99.06 & 99.11 \\
\hline
\end{tabular}

Annotations: $\mathrm{MS}=$ massive sulphide lens; $<\mathrm{DL}=$ below detection limit. 
Table 2. Average chemical compositions of the representative sphalerite in a stringer zone from the Bukit Botol deposit, Central Peninsular Malaysia.

\begin{tabular}{|c|c|c|c|c|c|c|c|}
\hline \multirow{2}{*}{$\begin{array}{c}\text { Deposit } \\
\text { Ore } \\
\text { Type/Sample }\end{array}$} & \multicolumn{7}{|c|}{ Bukit Botol } \\
\hline & SZ: BB2b & SZ: BB2b-A & SZ: BB2b-B & SZ: BB2b-C & SZ: BB2b-2A & SZ: BB2b-2B & $\begin{array}{c}\text { SZ: } \\
\text { BBotolDump-1 }\end{array}$ \\
\hline $\begin{array}{c}\text { No. spot } \\
\text { (Average wt\%) }\end{array}$ & 3 & 1 & 3 & 3 & 2 & 7 & 5 \\
\hline $\mathrm{S}$ & 34.21 & 36.07 & 32.89 & 32.71 & 32.70 & 33.03 & 32.81 \\
\hline $\mathrm{Pb}$ & 0.05 & $<\mathrm{DL}$ & $<\mathrm{DL}$ & 0.04 & 0.18 & 0.03 & $<\mathrm{DL}$ \\
\hline $\mathrm{Ag}$ & 0.03 & 0.09 & 0.05 & 0.02 & 0.10 & 0.05 & 0.01 \\
\hline $\mathrm{Cu}$ & 4.09 & 1.26 & 3.85 & 1.89 & 2.81 & 6.39 & 4.37 \\
\hline $\mathrm{Zn}$ & 53.79 & 54.94 & 58.65 & 62.35 & 60.44 & 53.48 & 57.25 \\
\hline Sn & $<\mathrm{DL}$ & $<\mathrm{DL}$ & $<\mathrm{DL}$ & $<\mathrm{DL}$ & $<\mathrm{DL}$ & $<\mathrm{DL}$ & $<\mathrm{DL}$ \\
\hline $\mathrm{Sb}$ & $<\mathrm{DL}$ & 0.04 & $<\mathrm{DL}$ & $<\mathrm{DL}$ & $<\mathrm{DL}$ & $<\mathrm{DL}$ & 0.01 \\
\hline As & $<\mathrm{DL}$ & $<\mathrm{DL}$ & $<\mathrm{DL}$ & $<\mathrm{DL}$ & $<\mathrm{DL}$ & $<\mathrm{DL}$ & 0.01 \\
\hline $\mathrm{Mn}$ & $<\mathrm{DL}$ & 0.01 & $<\mathrm{DL}$ & $<\mathrm{DL}$ & $<\mathrm{DL}$ & $<\mathrm{DL}$ & $<\mathrm{DL}$ \\
\hline $\mathrm{Fe}$ & 7.23 & 8.01 & 4.05 & 2.67 & 3.47 & 6.50 & 4.73 \\
\hline $\mathrm{Cd}$ & 0.22 & 0.24 & 0.24 & 0.26 & 0.28 & 0.23 & 0.22 \\
\hline \multicolumn{8}{|l|}{ Average } \\
\hline $\mathrm{Zn} / \mathrm{Mn}$ & 0 & 3951 & 0 & 0 & 0 & 0 & 0 \\
\hline $\mathrm{Zn} / \mathrm{Cd}$ & 239 & 229 & 251 & 245 & 216 & 230 & 267 \\
\hline $\mathrm{Zn} / \mathrm{Fe}$ & 12 & 7 & 21 & 23 & 20 & 13 & 16 \\
\hline \multicolumn{8}{|l|}{ Mole\% } \\
\hline $\mathrm{FeS}$ & 12.12 & 13.73 & 6.74 & 4.43 & 5.77 & 10.79 & 7.89 \\
\hline $\mathrm{CdS}$ & 0.22 & 0.25 & 0.24 & 0.26 & 0.28 & 0.23 & 0.22 \\
\hline CuS & 6.30 & 1.99 & 5.89 & 2.89 & 4.29 & 9.75 & 6.70 \\
\hline $\mathrm{ZnS}$ & 81.35 & 84.04 & 87.12 & 92.42 & 89.66 & 79.23 & 85.19 \\
\hline
\end{tabular}

Annotations: $\mathrm{SZ}=$ stringer zone; $<\mathrm{DL}=$ below detection limit.

Table 3. Average chemical compositions of the representative sphalerite in a massive sulphide layer from the Bukit Ketaya deposit, Central Peninsular Malaysia.

\begin{tabular}{|c|c|c|c|c|c|c|c|c|c|}
\hline \multirow{2}{*}{$\begin{array}{c}\text { Deposit } \\
\text { Ore } \\
\text { Type/Sample }\end{array}$} & \multicolumn{9}{|c|}{ Bukit Ketaya } \\
\hline & MS:BMSE1 & MS:BMSE1-A & MS: BK11A & $\begin{array}{c}\text { MS: } \\
\text { BK11B }\end{array}$ & MS: BK11 & $\begin{array}{c}\text { MS: } \\
\text { BK11-A }\end{array}$ & $\begin{array}{c}\text { MS: } \\
\text { BK11-B }\end{array}$ & $\begin{array}{c}\text { MS: } \\
\text { BK11-C }\end{array}$ & MS:BK11-D \\
\hline $\begin{array}{c}\text { No. spot } \\
\text { (Average } w t \%)\end{array}$ & 3 & 3 & 3 & 3 & 4 & 8 & 6 & 10 & 5 \\
\hline S & 32.93 & 32.76 & 33.07 & 33.08 & 32.26 & 32.46 & 32.35 & 32.37 & 32.57 \\
\hline $\mathrm{Pb}$ & $<\mathrm{DL}$ & $<\mathrm{DL}$ & $<\mathrm{DL}$ & $<\mathrm{DL}$ & 0.04 & $<\mathrm{DL}$ & $<\mathrm{DL}$ & $<\mathrm{DL}$ & 0.03 \\
\hline $\mathrm{Ag}$ & $<\mathrm{DL}$ & 0.02 & 0.06 & $<\mathrm{DL}$ & 0.04 & 0.03 & $<\mathrm{DL}$ & 0.01 & 0.02 \\
\hline $\mathrm{Cu}$ & $<\mathrm{DL}$ & 0.19 & $<\mathrm{DL}$ & $<\mathrm{DL}$ & $<\mathrm{DL}$ & $<\mathrm{DL}$ & $<\mathrm{DL}$ & $<\mathrm{DL}$ & $<\mathrm{DL}$ \\
\hline $\mathrm{Zn}$ & 66.63 & 66.45 & 66.59 & 66.64 & 64.70 & 66.04 & 65.89 & 66.21 & 64.91 \\
\hline Sn & $<\mathrm{DL}$ & $<\mathrm{DL}$ & $<\mathrm{DL}$ & $<\mathrm{DL}$ & $<\mathrm{DL}$ & $<\mathrm{DL}$ & $<\mathrm{DL}$ & $<\mathrm{DL}$ & $<\mathrm{DL}$ \\
\hline $\mathrm{Sb}$ & $<\mathrm{DL}$ & $<\mathrm{DL}$ & 0.02 & $<\mathrm{DL}$ & 0.02 & $<\mathrm{DL}$ & $<\mathrm{DL}$ & $<\mathrm{DL}$ & $<\mathrm{DL}$ \\
\hline As & $<\mathrm{DL}$ & $<\mathrm{DL}$ & $<\mathrm{DL}$ & $<\mathrm{DL}$ & 0.01 & $<\mathrm{DL}$ & $<\mathrm{DL}$ & $<\mathrm{DL}$ & $<\mathrm{DL}$ \\
\hline $\mathrm{Mn}$ & $<\mathrm{DL}$ & $<\mathrm{DL}$ & 0.01 & 0.00 & $<\mathrm{DL}$ & $<\mathrm{DL}$ & $<\mathrm{DL}$ & 0.01 & 0.00 \\
\hline $\mathrm{Fe}$ & 0.39 & 0.50 & 0.35 & 0.19 & 0.20 & 0.19 & 0.19 & 0.29 & 0.18 \\
\hline $\mathrm{Cd}$ & 0.23 & 0.25 & 0.18 & 0.20 & 0.21 & 0.21 & 0.20 & 0.20 & 0.20 \\
\hline \multicolumn{10}{|l|}{ Average } \\
\hline $\mathrm{Zn} / \mathrm{Mn}$ & 0 & 0 & 3356 & 1610 & 0 & 0 & 0 & 2028 & 692 \\
\hline $\mathrm{Zn} / \mathrm{Cd}$ & 285 & 265 & 371 & 336 & 313 & 321 & 325 & 330 & 337 \\
\hline $\mathrm{Zn} / \mathrm{Fe}$ & 172 & 140 & 195 & 347 & 332 & 356 & 350 & 237 & 370 \\
\hline \multicolumn{10}{|l|}{ Mole\% } \\
\hline $\mathrm{FeS}$ & 0.64 & 0.83 & 0.58 & 0.32 & 0.34 & 0.32 & 0.32 & 0.49 & 0.31 \\
\hline CdS & 0.23 & 0.25 & 0.18 & 0.20 & 0.22 & 0.22 & 0.21 & 0.20 & 0.21 \\
\hline CuS & 0 & 0.29 & 0 & 0 & 0 & 0 & 0 & 0 & 0 \\
\hline $\mathrm{ZnS}$ & 99.13 & 98.62 & 99.23 & 99.48 & 99.44 & 99.46 & 99.47 & 99.31 & 99.48 \\
\hline
\end{tabular}

Annotations: MS = massive sulphide lens; $<\mathrm{DL}=$ below detection limit.

The plot of the mole\% FeS versus mole\% CuS diagram shows that the CuS concentrations of sphalerite are at a high level for the two mineralisation types at both deposits (Figure 5a). Sphalerite from the stringer sulphide exhibits significant high content, from $<$ DL to more than 9.7 mole\% CuS. The majority of the sphalerite samples from the massive sulphide contain an amount between $<$ DL and 0.5 mole $\%$ CuS ( 5 out of 16 samples). 
Table 4. Average chemical compositions of the representative sphalerite in the stringer zone from the Bukit Ketaya deposit, Central Peninsular Malaysia.

\begin{tabular}{|c|c|c|c|c|c|c|c|c|}
\hline \multirow{2}{*}{$\begin{array}{c}\text { Deposit } \\
\text { Ore } \\
\text { Type/Sample }\end{array}$} & \multicolumn{8}{|c|}{ Bukit Ketaya } \\
\hline & SZ: BKCL1 & $\begin{array}{c}\text { SZ: } \\
\text { BKCL1-A }\end{array}$ & $\begin{array}{c}\text { SZ: } \\
\text { BKCL1-B }\end{array}$ & $\begin{array}{c}\text { SZ: } \\
\text { BKCL1-C }\end{array}$ & $\begin{array}{c}\text { SZ: } \\
\text { BKCL1-D }\end{array}$ & $\begin{array}{c}\text { SZ: } \\
\text { BKCL1-E }\end{array}$ & $\begin{array}{c}\text { SZ: } \\
\text { BKCL1-F }\end{array}$ & SZ:BK12a \\
\hline $\begin{array}{c}\text { No. spot } \\
\text { (Average wt } \% \text { ) }\end{array}$ & 6 & 5 & 6 & 7 & 7 & 10 & 4 & 3 \\
\hline S & 33.07 & 33.13 & 32.98 & 33.06 & 33.02 & 33.09 & 33.30 & 33.07 \\
\hline $\mathrm{Pb}$ & $<\mathrm{DL}$ & $<\mathrm{DL}$ & $<\mathrm{DL}$ & $<\mathrm{DL}$ & 0.00 & 0.02 & $<\mathrm{DL}$ & $<\mathrm{DL}$ \\
\hline $\mathrm{Ag}$ & $<\mathrm{DL}$ & $<\mathrm{DL}$ & $<\mathrm{DL}$ & 0.02 & 0.02 & 0.02 & 0.02 & $<\mathrm{DL}$ \\
\hline $\mathrm{Cu}$ & 0.20 & 0.17 & 0.53 & 0.07 & 0.08 & 0.10 & 0.37 & 0.75 \\
\hline $\mathrm{Zn}$ & 65.85 & 65.98 & 65.16 & 66.08 & 65.99 & 65.86 & 64.57 & 64.97 \\
\hline Sn & $<\mathrm{DL}$ & $<\mathrm{DL}$ & $<\mathrm{DL}$ & $<\mathrm{DL}$ & 0.01 & $<\mathrm{DL}$ & $<\mathrm{DL}$ & $<\mathrm{DL}$ \\
\hline $\mathrm{Sb}$ & $<\mathrm{DL}$ & $<\mathrm{DL}$ & $<\mathrm{DL}$ & $<\mathrm{DL}$ & 0.01 & $<\mathrm{DL}$ & $<\mathrm{DL}$ & $<\mathrm{DL}$ \\
\hline As & $<\mathrm{DL}$ & $<\mathrm{DL}$ & $<\mathrm{DL}$ & $<\mathrm{DL}$ & 0.01 & $<\mathrm{DL}$ & $<\mathrm{DL}$ & $<\mathrm{DL}$ \\
\hline $\mathrm{Mn}$ & 0.05 & 0.05 & 0.01 & 0.13 & 0.06 & 0.03 & 0.00 & 0.02 \\
\hline $\mathrm{Fe}$ & 0.64 & 0.55 & 0.83 & 0.53 & 0.58 & 0.52 & 0.71 & 0.87 \\
\hline $\mathrm{Cd}$ & 0.30 & 0.29 & 0.30 & 0.27 & 0.27 & 0.30 & 0.29 & 0.52 \\
\hline \multicolumn{9}{|l|}{ Average } \\
\hline $\mathrm{Zn} / \mathrm{Mn}$ & 1613 & 1405 & 2713 & 529 & 1157 & 1424 & 1193 & 3253 \\
\hline $\mathrm{Zn} / \mathrm{Cd}$ & 230 & 229 & 221 & 246 & 241 & 225 & 225 & 125 \\
\hline $\mathrm{Zn} / \mathrm{Fe}$ & 112 & 122 & 83 & 126 & 117 & 130 & 119 & 77 \\
\hline \multicolumn{9}{|l|}{ Mole\% } \\
\hline $\mathrm{FeS}$ & 1.06 & 0.91 & 1.38 & 0.88 & 0.96 & 0.86 & 1.19 & 1.44 \\
\hline $\mathrm{CdS}$ & 0.30 & 0.29 & 0.30 & 0.27 & 0.27 & 0.30 & 0.30 & 0.52 \\
\hline CuS & 0.30 & 0.26 & 0.81 & 0 & 0 & 0 & 0.57 & 1.14 \\
\hline $\mathrm{ZnS}$ & 98.33 & 98.54 & 97.51 & 98.85 & 98.77 & 98.83 & 97.94 & 96.90 \\
\hline
\end{tabular}

Annotations: $\mathrm{SZ}=$ stringer zone; $<\mathrm{DL}=$ below detection limit.
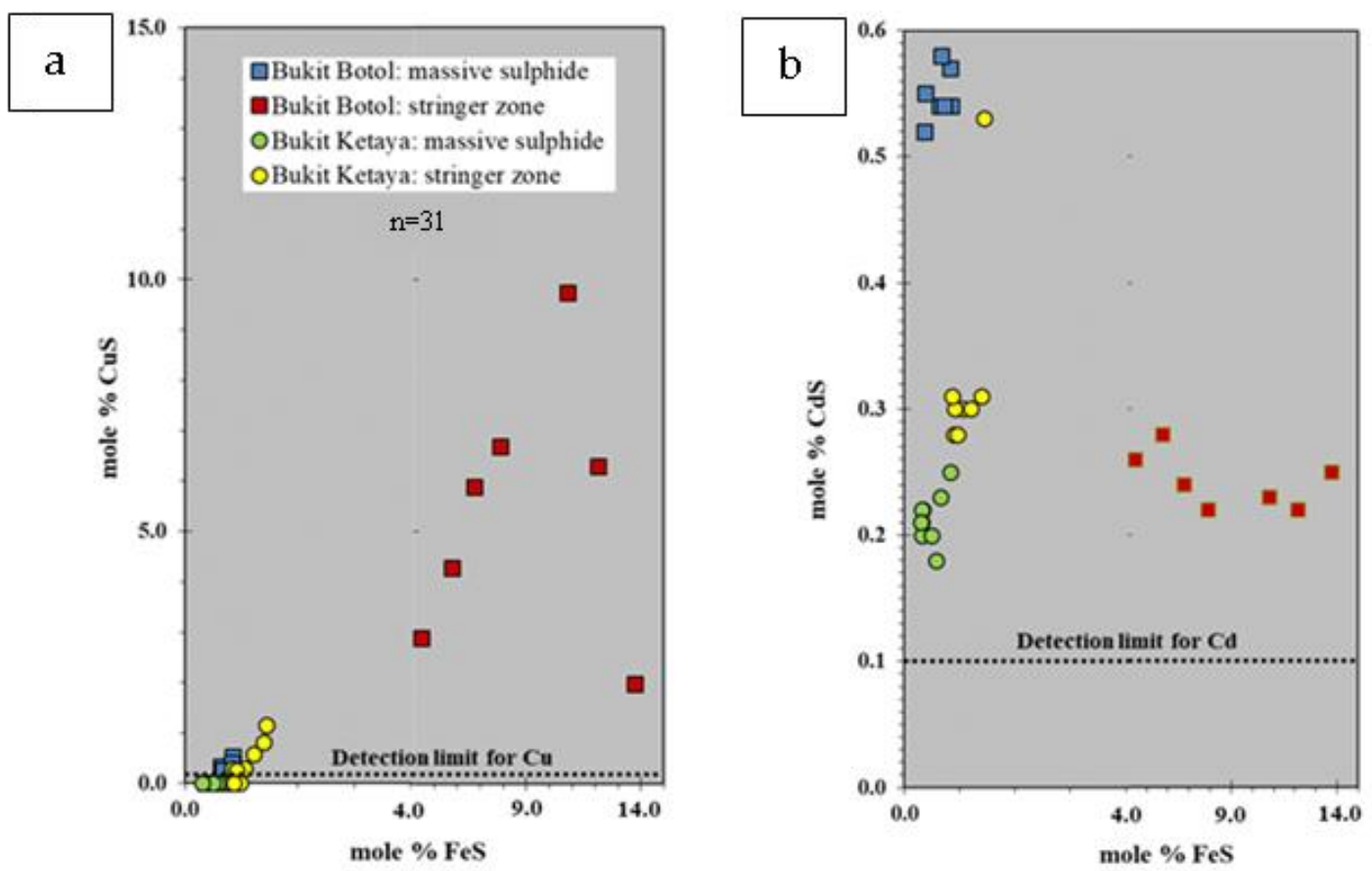

Figure 5. Plot showing mole\% FeS, CuS and CdS variations in sphalerite from the Bukit Botol and Bukit Ketaya deposits, Central Peninsular Malaysia. (a) The relations between mole $\% \mathrm{CuS}$ and mole $\%$ FeS. (b) The relationships between mole\% CdS and mole\% FeS.

The relationship between the FeS and CdS compositions of the sphalerite from both the Bukit Botol and Bukit Ketaya deposits is displayed on a binary plot shown in Figure 5b. The CdS concentrations of all the studied samples are mainly in the range of 0.2 to $0.6 \mathrm{~mole} \%$ CdS. The mole $\%$ CdS in the sphalerite from massive sulphide at Bukit Botol is significantly higher than that from the stringer sulphide. The $\mathrm{Cd}$ value is generally more than 0.5 
mole\% CdS for the sphalerite in the massive sulphide, whereas a nearly constant value (approximately 0.3 mole $\% \mathrm{CdS}$ ) is recorded in the sphalerite from the stringer sulphide. In comparison, sphalerites from both the massive and stringer sulphides of the Bukit Ketaya display a narrow range from 0.2 to $0.3 \mathrm{~mole} \% \mathrm{CdS}$.

Table 5 displays the average values of $\mathrm{Zn} / \mathrm{Mn}, \mathrm{Zn} / \mathrm{Cd}$, and $\mathrm{Zn} / \mathrm{Fe}$ ratios of sphalerite from different mineralisation styles at the Bukit Botol and Bukit Ketaya deposits. It is also noted that the higher Zn/Mn (1149), lower Zn/Cd (123), and higher Zn/Fe (200) values of sphalerite in massive sulphide, compared with the sphalerite in stringer sulphide $\mathrm{Zn} / \mathrm{Mn}$ (256), Zn/Cd (240) and Zn/Fe (16), are clearly shown from the Bukit Botol deposit. However, only small variations of $\mathrm{Zn} / \mathrm{Mn}, \mathrm{Zn} / \mathrm{Cd}$, and $\mathrm{Zn} / \mathrm{Fe}$ ratios are displayed by sphalerite associated with the massive and stringer sulphides from the Bukit Ketaya deposit. The massive sulphide shows average $\mathrm{Zn} / \mathrm{Mn}$ (854), $\mathrm{Zn} / \mathrm{Cd}$ (320), and $\mathrm{Zn} / \mathrm{Fe}$ (278), whereas the stringer sulphides exhibit $\mathrm{Zn} / \mathrm{Mn}$ (1161), Zn/Cd (218), and Zn/Fe (111).

Table 5. Average $\mathrm{Zn} / \mathrm{Mn}, \mathrm{Zn} / \mathrm{Cd}$, and $\mathrm{Zn} /$ Fe ratios of sphalerites from the Bukit Botol and Bukit Ketaya deposits.

\begin{tabular}{cccc}
\hline Deposit \& Ore Types & Zn/Mn Ratio & Zn/Cd Ratio & Zn/Fe Ratio \\
\hline Bukit Botol & & & \\
massive sulphide $(n=7)$ & 1149 & 123 & 200 \\
stringer sulphide $(n=7)$ & 256 & 240 & 16 \\
Bukit Ketaya & & & \\
massive sulphide $(n=9)$ & 854 & 320 & 278 \\
stringer sulphide $(n=8)$ & 1161 & 218 & 111 \\
\hline
\end{tabular}

\section{Discussion}

\subsection{Trace Element Variation and Substitution}

The chemical composition of sphalerite varies significantly with the location and type of ore deposits. However, the amount of FeS in sphalerite is mainly controlled by the temperature, $\mathrm{pH}$, pressure, and aFeS (average FeS content) in any of these ore deposition environments (e.g., [13]), as well as the sulphur activity of the fluid [48]. Urabe, T. [15] reported that the FeS content in sphalerite from several Kuroko deposits in Japan decreases with decreasing temperature of formation. Scott, S.D $[8,16,49,50]$ considered that the FeS content of sphalerite can be used to constrain sulphur activity in ore-forming fluids, but is dependent on total sulphur concentration during mixing of the ore fluids with seawater provided metamorphism has not requilibrated FeS contents during recrystallization [16].

In the Bukit Botol deposit, variations of FeS content are clearly shown by the sphalerite from the different mineralisation styles indicating high $\mathrm{FeS}$ content in the stringer zones and low contents in the massive sulphide. Although the FeS content in sphalerite at the Bukit Ketaya deposit is more homogeneous with a narrow range in compositions (0.3-2.5 mole $\% \mathrm{FeS}$ ), the trend also shows a slight increase from massive sulphide towards the stringer zone. Thus, a declining trend is suggested in FeS from the lower to the upper stratigraphic levels at both deposits. These data are in agreement with the similar trends in sphalerite signatures in the proximal-distal transition of Kuroko deposits [15]. Therefore, the relatively lower FeS contents of sphalerite in the massive sulphide at both deposits suggest high sulphidation conditions and lower temperatures of formation, whereas higher FeS contents of sphalerite in the stringer sulphide can be related to the higher temperature conditions at the Tasik Chini deposit. This suggestion is also supported by a similar pattern of sulphur isotopes at both the deposits, which display an increase of $\delta^{34} S$ value from the stringer zone to the massive sulphide through to barite mineralisations [42].

The authors of [51] conducted a study on the distribution of trace elements in sulphide minerals from a number of Australian VHMS deposits and they found the Cu concentrations in sphalerite were generally detected and uniform within samples (most values between 1000 and $4500 \mathrm{ppm}$ ), except for very high values to $2.18 \mathrm{wt} \%$. Despite that, [5] reported that the $\mathrm{Cu}$ concentration in sphalerite varies with the metamorphic grade of the 
sulphide deposits, respectively. The upper grade deposits show significant homogeneity in their $\mathrm{Cu}$ concentrations even in the presence of co-existing chalcopyrite, whereas the lower grade deposits showed higher mean $\mathrm{Cu}$ concentrations overall, and were affected by very high individual $\mathrm{Cu}$ values [5].

Sphalerite from stringers mineralisation are enriched in $\mathrm{Cu}$ relative to sphalerite from massive sulphide mineralisation. This behaviour is consistent with the concentration of $\mathrm{Fe}$ decreases across the stringer zone to the massive sulphide mineralisations, respectively. As discussed previously, these results show that the solubility and mobility of $\mathrm{Cu}$ in the ore fluid are related to temperature conditions. Accordingly, the precipitation temperature of sphalerite from the stringer zone is relatively higher than sphalerite from massive sulphide mineralisation. Moreover, the relatively high Cu contents ranging up to $4.4 \mathrm{wt} \%$ in the majority of sphalerite from different types of mineralisations at the Bukit Botol and Bukit Ketaya deposits are consistent with and also far above the primary $\mathrm{Cu}$ contents in sphalerite $(<2 \mathrm{wt} \% ;[51,52])$. Further consideration of the chemical composition and textural evidence suggests that higher $\mathrm{Cu}$ concentrations in sphalerites from both the deposits could reflect the occurrence of both $\mathrm{Cu}$-rich micro to nano inclusions and lattice-bound $\mathrm{Cu}$ in sphalerite samples from these two deposits. This is in agreement with [51], which argued that the lower, uniform $\mathrm{Cu}$ levels in sphalerite probably result from the solution of CuS into the sphalerite lattice, whereas higher values most likely result from inclusions of chalcopyrite. Additionally, this is also supported by [5], who remarked that microanalysis of sphalerite often cannot reveal homogeneous distributions within individual sampled volume due to the difficulty of discriminating between elements hosted within crystal lattice and elements hosted within nano-scale inclusions of sphalerite.

Recent work has shown that Ag exhibits a dual character, either as micro-inclusions of Ag-bearing minerals (i.e., tetrahedrite-tennantite) in sphalerite, as well as substituted in the lattice (as Ag) [4,6,53]. Although the concentrations of Ag in sphalerite is difficult to interpret with the available analytical resolution, the highest and elevated $\mathrm{Ag}$ concentrations in the samples from the Bukit Botol and Bukit Ketaya deposits may suggest most likely the presence of micro-inclusions of Ag-hosting minerals, rather than the substitution of Ag into the crystal lattice of the host sphalerite. This interpretation is supported by ore mineralogy and paragenesis characteristics at both the deposits, which show an occurrence of Agbearing minerals (mckinstryite, $\mathrm{AgCuS}$ and native silver) throughout the mineralisation zones [44]. Overall, the chemical composition ranges of sphalerite, either as solid solution, nanoparticles, and micro inclusions [4,54-58] exhibited in both the Bukit Botol and Bukit Ketaya deposits are consistent with published results of a few VHMS deposits, such as the Kuroko deposits, Japan [15] and the Rosebery-Hercules deposits, Tasmania [13].

\subsection{Implications of Major and Trace Element Abundances in Sphalerite to Ore Genesis}

The $\mathrm{Cd}$ content and the $\mathrm{Zn} / \mathrm{Cd}$ ratios of sphalerite have been used as distinguishing parameters for ore deposit types. According to a classification based on a compilation of literature data by $[59,60]$, the Cd concentrations in sphalerite from VHMS deposits $($ mean $=2360 \mathrm{ppm})$ and SEDEX deposits $($ mean $=2560 \mathrm{ppm})$ are the lowest. MVT and veins in carbonate rock deposits have the highest $\mathrm{Cd}$ content (mean between 4850 and $7260 \mathrm{ppm}$ ), whereas the moderate $\mathrm{Cd}$ values are characterised by skarn and veins in low carbonate rock deposits (mean from 3540 to $4100 \mathrm{ppm}$ ).

The author of [61] calculated $\mathrm{Zn} / \mathrm{Cd}$ ratios and average values in sphalerite from various genetic types of deposits. He also reported that the volcano-sedimentary and Alpine (MVT) type deposits have the highest $\mathrm{Zn} / \mathrm{Cd}$ ratios of 417 to 531. The hydrothermal deposits, including vein magmatic related and skarn deposits, exhibit the lowest $\mathrm{Zn} / \mathrm{Cd}$ ratios between 104 and 214, with the metamorphosed sedimentary carbonatehosted stratiform deposits showing moderate $\mathrm{Zn} / \mathrm{Cd}$ ratios (252-330). Moreover, the relatively higher $\mathrm{Zn} / \mathrm{Cd}$ values ranging between 250 and 400 were considered to be related to volcanic source rocks, as for example, those of the Valu Fa Ridge, Pacific Ocean [62], and Roseberry-Hercules Cambrian VHMS deposits [13]. Meanwhile, $\mathrm{Zn} / \mathrm{Cd}$ ratios lower 
than 250 are thought to be associated with granitic magmatism as for instances such as the Devonian $\mathrm{Pb}-\mathrm{Zn}$ vein deposits in western Tasmania [13].

Recent evidence for the classification of $\mathrm{Pb}-\mathrm{Zn}$ deposits show that the $\mathrm{Cd}$ concentrations from deposits of high-temperature systems group (porphyry, skarn, and VMS), yielded a mean value of $2932 \mathrm{ppm}$ and ranged from 2410 to $4126 \mathrm{ppm}$, and the $\mathrm{Zn} / \mathrm{Cd}$ ratios varied from 155 to 223 with a mean value of 195 [60].

The sphalerite from both the Bukit Botol and Bukit Ketaya deposits show $\mathrm{Cd}$ values ranging within 1800 to $5700 \mathrm{ppm}$ (average $=3187 \mathrm{ppm}$ ). However, the $\mathrm{Zn} / \mathrm{Cd}$ ratios in sphalerite for the Bukit Botol deposit vary with an average of 123 for the massive sulphide and 240 for the stringer zones, whereas the ratios of $\mathrm{Zn} / \mathrm{Cd}$ at the Bukit Ketaya deposit exhibit an average of 320 in the massive sulphide and 218 in the stringer zones. In comparison, these data demonstrate that the low $\mathrm{Cd}$ concentration in sphalerite at both the Bukit Botol and Bukit Ketaya deposits is comparable with the lowest Cd content in many VHMS and SEDEX deposits as compiled by [59], and show an even distribution of Cd in sample or even deposit scale, which are consistent with observations from other metamorphosed sphalerite-bearing massive sulphide deposits [5]. Additionally, the variability of the $\mathrm{Zn} / \mathrm{Cd}$ ratio in sphalerite from both these deposits is comparable to those of the volcano-sedimentary deposits with a volcanic origin as calculated by [61].

This result strongly suggests that the mixing of sulphur and metal carrying fluids was a crucial process for ore formation in the Tasik Chini VHMS deposits. The mixing of different fluids (seawater dominant and minor magmatic fluids), based on the $\mathrm{S}, \mathrm{Pb}$ isotopes of sulphide minerals and pyrite chemistry data, is considered responsible for controlling the chemistry of the sphalerite at both the Bukit Botol and Bukit Ketaya deposits [42-44], similar to the Eskay Creek VHMS deposit, Canada, as was suggested by [63]. Furthermore, the complex relationship of $\mathrm{Zn} / \mathrm{Cd}$ ratios in sphalerite between the Bukit Botol and Bukit Ketaya deposits is also interpreted probably due to the differences in temperature, $\mathrm{pH}$, salinity, pressure, and aFeS (average FeS content) contributions during their deposition as reported in other similar deposits (e.g., [13]).

\section{Conclusions}

(1) The sphalerite chemistry studied by electron microprobe reveals that the Bukit Botol and Bukit Ketaya deposits display similarities in FeS concentrations in both massive sulphides and stringer zones.

(2) Trends of FeS and other major or trace elements content in sphalerite either as a solid solution, nanoparticles and micro-inclusions are consistent with published results of VHMS deposits worldwide, and probably controlled by kinetic effects and substitution mechanisms.

(3) Although the application of sphalerite alone as a geobarometer cannot be used because of the absence of sphalerite-pyrite-hexagonal pyrrhotite assemblage, the sphalerite composition data, such as $\mathrm{Cd}$ content and $\mathrm{Zn} / \mathrm{Cd}$ ratios, are consistent with those exhibited in other VHMS deposits.

Author Contributions: M.B.I.B., K.Z., R.R.L. and S.E.G. elaborated the subject and main idea of the manuscript; M.B.I.B. collected and performed sample preparation, and acquired analytical data; M.B.I.B. processed the acquired data and wrote the manuscript; S.E.G., K.Z. and R.R.L. revised and edited the final manuscript. All authors have read and agreed to the published version of the manuscript.

Funding: This research was funded by THE NATIONAL UNIVERSITY OF MALAYSIA (UKM), grant number GUP-2020-031" and "The APC was funded by THE NATIONAL UNIVERSITY OF MALAYSIA (UKM), grant number GUP-2020-031".

Data Availability Statement: Data is contained within the manuscript.

Acknowledgments: This research forms part of the first author's PhD thesis at CODES, University of Tasmania, Australia, and was supported financially by the Ministry of Higher Education of Malaysia (MOHE) and The National University of Malaysia (UKM), as well as additional research university 
funding [grant/award number: GUP-2020-031]. Additional field studies and lapidary services were provided by the "Ore Deposit of SE Asia" project led by Khin Zaw. We acknowledge Mazlinfalina Mohd Zin for analytical assistance. We also thank the Editor, Guest Editors and Assistant Editors of Minerals for editorial handling of the manuscript, and four anonymous Minerals reviewers for their helpful comments which helped us improve this manuscript.

Conflicts of Interest: The authors declare no conflict of interest. The funders had no role in the design of the study; in the collection, analyses, or interpretation of data; in the writing of the manuscript, or in the decision to publish the results.

\section{References}

1. Chon, H.T.; Shimazaki, H.; Sato, K. Compositional variation of sphalerites from some hydrothermal metallic ore deposits in the Republic of Korea. Min. Geol. 1981, 31, 337-343.

2. Shimazaki, H.; Shimizu, M. Compositional variation of sphalerites from skarn deposits in Japan. J. Fac. Sci. Univ. Tokyo Sect. II 1984, 21, 1-37.

3. Barton, P.B., Jr.; Bethke, P.M. Chalcopyrite disease in sphalerite: Pathology and epidemiology. Am. Mineral. 1987, $72,451-467$.

4. Cook, N.J.; Ciobanu, C.L.; Pring, A.; Skinner, W.; Shimizu, M.; Danyushevsky, L.; Saini-Eidukat, B.; Melcher, F. Trace and minor elements in sphalerite: A LA-ICPMS study. Geochim. Cosmochim. Acta 2009, 73, 4761-4791. [CrossRef]

5. Lockington, J.A.; Cook, N.J.A.; Ciobanu, C.L. Trace and minor elements in sphalerite from metamorphosed sulfide deposits. Mineral. Petrol. 2014, 108, 873-890. [CrossRef]

6. Murakami, H.; Ishihara, S. Trace elements of Indium-bearing sphalerite from tin-polymetallic deposits in Bolivia, China and Japan: A femto-second LA-ICPMS study. Ore Geol. Rev. 2013, 53, 223-243. [CrossRef]

7. Kullerud, G. The FeS-ZnS system, a geological thermometer. Nor. Geol. Tidsskr. 1953, 32, 61-147.

8. Scott, S.D.; Barnes, H.L. Sphalerite geothermometry and geobarometry. Econ. Geol. 1971, 66, 653-669. [CrossRef]

9. Hutchison, M.N.; Scott, S.D. Sphalerite geobarometry in the Cu-Fe-Zn-S system. Econ. Geol. 1981, 76, 143-153. [CrossRef]

10. Moles, N.R. Sphalerite composition in relation to deposition and metamorphism of the Foss stratiform Ba-Zn-Pb deposit, Aberfeldy, Scotland. Mineral. Mag. 1983, 47, 487-500. [CrossRef]

11. Sundblad, K. A genetic reinterpretation of the Falun and Ammeberg ore types, Bergslagen, Sweden. Miner. Depos. 1994, 29, 170-179. [CrossRef]

12. Brill, B.A. Trace element contents and partitioning of elements in ore minerals from the CSA Cu-Pb-Zn deposit, Australia. Can . Mineral. 1989, 27, 263-274.

13. Zaw, K.; Large, R.R. Petrology and geochemistry of sphalerite from the Cambrian VHMS deposits in the Roseberry Hercules district, Western Tasmania: Implications for gold mineralisation and Devonian metamorphic-metasomatic processes. Mineral. Petrol. 1996, 57, 97-118. [CrossRef]

14. Wright, K.; Julian, G. A first principles study of the distribution of iron in sphalerite. Geochim. Cosmochim. Acta 2010, 74, 3514-3520. [CrossRef]

15. Urabe, T. Iron content of sphalerite coexisting with pyrite from some Kuroko deposits. Soc. Min. Geol. Jpn. Spec. 1974, 377-384.

16. Hannington, M.D.; Scott, S.D. Sulfidation equilibria as guides to gold mineralization in volcanogenic massive sulfides: Evidence from sulfide mineralogy and the composition of sphalerite. Econ. Geol. 1989, 84, 1978-1995. [CrossRef]

17. Ames, D.E.; Franklin, J.M.; Hannington, M.D. Mineralogy and geochemistry of active and inactive chimneys and massive sulfide, Middle Valley, northern Juan de Fuca Ridge; an evolving hydrothermal system. Can. Mineral. 1993, 31, 997-1024.

18. Hill, A.P. Structure, Volcanic Setting, Hydrothermal Alteration and Genesis of the Thalanga Massive Sulphide Deposit. Ph.D. Thesis, University of Tasmania, Hobart, TAS, Australia, 1996.

19. Hannington, M.D.; Bleeker, W.; Kjarsgaard, I. Sulphide mineralogy, geochemistry, and genesis of the Kidd Creek deposit: Part I. North, Central, and South orebodies. Econ. Geol. Monogr. 1999, 10, 163-224.

20. Hekinian, R.; Fevrier, M.; Bischoff, J.L.; Picot, P.; Shanks, W.C., III. Sulfide deposits from the East Pacific Rise near $21^{\circ}$ N. Science 1980, 207, 1433-1444. [CrossRef]

21. Peter, J.M.; Scott, S.D. Mineralogy, composition and fluid inclusion microthermometry of seafloor hydrothermal deposits in the southern trough of Guaymas Basin, Gulf of California. Can. Mineral. 1988, 26, 567-587.

22. Moss, R.; Scott, S.D. Geochemistry and mineralogy of gold-rich hydrothermal precipitates from the eastern Manus Basin, Papua New Guinea. Can. Mineral. 2001, 39, 957-978. [CrossRef]

23. Styrt, M.M.; Brackmann, A.J.; Holland, H.D.; Clark, B.C.; Pisutha-Arnond, V.; Eldridge, C.S.; Ohmoto, H. The mineralogy and the isotopic composition of sulfur in hydrothermal sulfide/sulfate deposits on the East Pacific Rise, $21^{\circ} \mathrm{N}$ latitude. Earth Planet. Sci. Lett. 1981, 53, 382-390. [CrossRef]

24. Zierenberg, R.A.; Shanks, W.C., III; Bischoff, J.L. Massive sulfide deposits at $21^{\circ}$ N, East Pacific Rise: Chemical composition, stable isotopes, and phase equilibria. Geol. Soc. Am. Bull. 1984, 95, 922-929. [CrossRef]

25. Metcalfe, I. Tectonic evolution of the Malay Peninsula. J. Asian Earth Sci. 2013, 76, 195-213. [CrossRef]

26. Gobbett, D.J.; Hutchison, C.S. Geology of the Malay Peninsula; Wiley-Interscience: New York, NY, USA, 1973 ; p. 438.

27. Metcalfe, I. Permian Tectonic Framework and Paleogeography of SE Asia. J. Asian Earth Sci. 2002, 20, 551-566. [CrossRef] 
28. Hutchison, C.S. Geological Evolution of South-East Asia; Geological Society of Malaysia: Kuala Lumpur, Malaysia, $2007 ;$ p. 433.

29. Ghani, A.A. Plutonism. In Geology of Peninsular Malaysia; Hutchison, C.S., Tan, D.N.K., Eds.; University of Malaya and the Geological Society of Malaysia: Kuala Lumpur, Malaysia, 2009; pp. 211-223.

30. Ghani, A.A. Volcanism. In Geology of Peninsular Malaysia; Hutchison, C.S., Tan, D.N.K., Eds.; University of Malaya and the Geological Society of Malaysia: Kuala Lumpur, Malaysia, 2009; pp. 197-210.

31. Searle, M.P.; Whitehouse, M.J.; Robb, L.J.; Ghani, A.; Hutchison, C.S.; Sone, M.; Ng, W.P.; Roselee, M.H.; Chung, S.L.; Oliver, G.J.H. Tectonic evolution of the Sibumasu-Indochina terrane collision zone in Thailand and Malaysia constraints from new $\mathrm{U}$ - $\mathrm{Pb}$ zircon chronology of SE Asian tin granitoids. J. Geol. Soc. Lond. 2012, 169, 489-500. [CrossRef]

32. MacDonald, S. Geology and Mineral Resources of the Lake Chini-Sungei Bera-Sungei Jeram Area of South-Central Pahang, (Geological Survey Malaysia Map Bulletin 1); Ministry of Lands and Mines: Kuala Lumpur, Malaysia, 1970.

33. Basori, M.B.I. Geology and Genesis of Volcanic-Hosted Massive Sulphide Deposits in the Tasik Chini District, Central Peninsular Malaysia. Ph.D. Thesis, University of Tasmania, Hobart, TAS, Australia, 2014.

34. Basori, M.B.I.; Zaw, K.; Meffre, S.; Large, R.R. Geochemistry, geochronology, and tectonic setting of early Permian ( 290 Ma) volcanic-hosted massive sulphide deposits of the Tasik Chini district, Peninsular Malaysia. Int. Geol. Rev. 2016, 58, 929-948. [CrossRef]

35. Hutchinson, R.W. Massive sulphide deposits and their possible significant to other ores in Southeast Asia. Bull. Geol. Soc. Malaysia 1986, 19, 1-22. [CrossRef]

36. Teh, G.H.; Shahrul, A.A.; Suhaimi, H.M.; Wood, A.K.H. Gold and REE distribution patterns in Tasik Cini volcanogenic massive sulphide deposits. War. Geol. 1991, 17, 159.

37. Teh, G.H.; Osman, M.H.; Ahmad, S.A.; Aziz, J.H.A. Invisible gold in massive sulphides at Tasik Chini, Pahang. War. Geol. 2004, 30, 33-36.

38. Basori, M.B.I.; Gilbert, S.; Large, R.R.; Zaw, K. Origin of Fe-Mn \pm Si layers associated with the Permian volcanic-hosted massive sulphide deposits in the Tasik Chini district, Peninsular Malaysia. J. Asian Earth Sci. 2020, 192, 104260. [CrossRef]

39. Sone, M.; Metcalfe, I. Parallel Tethyan sutures in mainland Southeast Asia: New insights for Palaeo-Tethys closure and implications for the Indosinian orogeny. Comptes Rendus Geosci. 2008, 340, 166-179. [CrossRef]

40. Zaw, K.; Meffre, S.; Lai, C.K.; Santosh, M.; Burrett, F.C.; Graham, I.T.; Manaka, T.; Salam, A.; Kamvong, T.; Cromie, P. Tectonics and metallogeny of mainland SE Asia-A review and contribution. Special issue on tectonics and metallogeny of mainland SE Asia. Gondwana Res. 2014, 26, 5-30.

41. Sevastjanova, I.; Clements, B.; Hall, R.; Belousova, E.A.; Griffin, W.L.; Pearson, N. Granitic magmatism, basement ages, and provenance indicators in the Malay Peninsula: Insights from detrital zircon U-Pb and Hf-isotope data. Gondwana Res. 2011, 19, 1024-1039. [CrossRef]

42. Basori, M.B.I.; Zaw, K.; Large, R.R.; Hassan, W.F.W. Sulfur isotope characteristics of the Permian VHMS deposits in Tasik Chini district, Central Belt of Peninsular Malaysia. Turk. J. Earth Sci. 2017, 26, 91-103. [CrossRef]

43. Basori, M.B.I.; Zaw, K.; Meffre, S.; Large, R.R.; Hassan, W.F.W. Pb-isotope compositions of the Tasik Chini volcanic-hosted massive sulfide deposit, Central Belt of Peninsular Malaysia: Implication for source region and tectonic setting. Isl. Arc. 2017, 26 , e12177. [CrossRef]

44. Basori, M.B.I.; Gilbert, S.; Large, R.R.; Zaw, K. Textures and trace element composition of pyrite from the Bukit Botol volcanichosted massive sulphide deposit, Peninsular Malaysia. J. Asian Earth Sci. 2018, 158, 173-185. [CrossRef]

45. Basori, M.B.I.; Zaw, K.; Mernagh, T.P.; Large, R.R. Microthermometric evidence for the formation of Permian VHMS deposits in Tasik Chini district, Central Belt of Peninsular Malaysia. Ore Geol. Rev. 2019, 111, 102947. [CrossRef]

46. Helsel, D.R. Nondetects and Data Analysis: Statistics for Censored Environmental Data; Wiley: New York, NY, USA, 2005.

47. Whitney, D.L.; Evan, B.W. Abbreviations for names of rock-forming minerals. Am. Mineral. 2010, 95, 185-187. [CrossRef]

48. Scott, S.D.; Kissin, S.A. Sphalerite composition in the Zn-Fe-S system below $300{ }^{\circ}$ C. Econ. Geol. 1973, 68, 475-479. [CrossRef]

49. Barton, P.B., Jr.; Skinner, B.J. Sulfide mineral stabilities. In Geochemistry of Hydrothermal Ore Deposits; Barnes, H.L., Ed.; Wiley Interscience: New York, NY, USA, 1979; pp. 278-403.

50. Craig, J.R.; Vaughan, D.J. Ore Microscopy and Ore Petrography, 2nd ed.; Wiley: New York, NY, USA, $1994 ;$ p. 434.

51. Huston, D.L.; Sie, S.H.; Suter, G.F.; Cooke, D.R.; Both, R.A. Trace elements in sulfide minerals from eastern Australian volcanichosted massive sulfide deposits: Part I. Proton microprobe analyses of pyrite, chalcopyrite, and sphalerite, and Part II. Selenium levels in pyrite: Comparison with $\delta^{34} \mathrm{~S}$ values and implications for the source of sulfur in volcanogenic hydrothermal systems. Econ. Geol. 1995, 90, 1167-1196.

52. Kojima, S.; Sugaki, A. Phase relations in the Cu-Fe-Zn-S system between $500^{\circ}$ and $300{ }^{\circ} \mathrm{C}$ under hydrothermal conditions. Econ. Geol. 1985, 80, 158-171. [CrossRef]

53. Ciobanu, C.L.; Cook, N.J.; Utsunomiya, S.; Pring, A.; Green, L. Focussed ion beam-transmission electron microscopy applications in ore mineralogy: Bridging micro- and nanoscale observations. Ore Geol. Rev. 2011, 42, 6-31. [CrossRef]

54. Grammatikopoulos, T.A.; Valeyev, O.; Roth, T. Compositional variation in Hg-bearing sphalerite from the polymetallic Eskay Creek deposit, British Columbia, Canada. Chem. Erde 2006, 66, 307-314. [CrossRef]

55. Ye, L.; Cook, N.J.; Ciobanu, C.L.; Liu, Y.; Zhang, Q.; Liu, T.; Gao, W.; Yang, Y.; Danyushevskiy, L. Trace and minor elements in sphalerite from base metal deposits in South China: A LA-ICPMS study. Ore Geol. Rev. 2011, 39, 188-217. [CrossRef] 
56. Radosavljević, S.; Stojanović, J.N.; Radosavljević-Mihajlović, A.S.; Vuković, N.S. (Pb-Sb)-bearing sphalerite from the Čumavići polymetallic ore deposit, Podrinje Metallogenic District, East Bosnia and Herzegovina. Ore Geol. Rev. 2016, 72, 253-268. [CrossRef]

57. Keith, M.; Haase, K.M.; Schwarz-Schampera, U.; Klemd, R.; Petersen, S.; Bach, W. Effects of temperature, sulfur, and oxygen fugacity on the composition of sphalerite from submarine hydrothermal vents. Geology 2014, 42, 699-702. [CrossRef]

58. Wohlgemuth-Ueberwasser, C.C.; Viljoen, F.; Petersen, S.; Vorster, C. Distribution and solubility limits of trace elements in hydrothermal black smoker sulfides: An in-situ LA-ICP-MS study. Geochim. Cosmochim. Acta 2015, 159, 16-41. [CrossRef]

59. Schwartz, M.O. Cadmium in zinc deposits: Economic geology of a polluting element. Int. Geol. Rev. 2000, 42, 445-469. [CrossRef]

60. Wen, H.; Zhu, C.; Zhang, Y.; Cloquet, C.; Fan, H.; Fu, S. Zn/Cd ratios and cadmium isotope evidence for the classification of lead-zinc deposits. Sci. Rep. 2016, 6, 25273. [CrossRef]

61. Xuexin, S. Minor elements and ore genesis of the Fankou lead-zinc deposit, China. Miner. Depos. 1984, 19, 95-104. [CrossRef]

62. Fouquet, Y.; Wafic, A.; Cambon, P.; Mevel, C.; Meyer, C.; Gente, P. Tectonic setting and mineralogical and geochemical zonation in the Snake Pit Sulfide Deposit (Mid Atlantic Ridge at 23 N). Econ. Geol. 1993, 88, 2018-2036. [CrossRef]

63. Sherlock, R.L.; Roth, T.; Spooner, E.T.C.; Bray, C.J. Origin of the Eskay Creek precious metal-rich volcanogenic massive sulfide deposit: Fluid inclusion and stable isotope evidence. Econ. Geol. 1999, 94, 803-824. [CrossRef] 